\title{
COMPROMISING WITH DE-GLOBALIZATION OR SEIZING AN OPPORTUNITY? IMPLICATIONS OF THE COVID-19 PANDEMIC FOR FIRMS AND GOVERNMENTS
}

\author{
A. Yu. Panibratov, S. Chen \\ St. Petersburg State University, \\ 7-9, Universitetskaya nab., St. Petersburg, 199034, Russian Federation
}

For citation: Panibratov A. Yu., Chen S. 2021. Compromising with de-globalization or seizing an opportunity? Implications of the COVID-19 pandemic for firms and governments. Vestnik of Saint Petersburg University. Management 20 (3): 326-342. https://doi.org/10.21638/11701/spbu08.2021.302

This paper is an attempt to explore the responsive national policies and business strategies based on evaluation of the impacts of COVID-19. While the world economy is recovering from the pandemic, many business activities have been dramatically depressed. The tendency of deglobalization is emerging, accompanied by the digitalization of communication and transformation of industries. It is worth considering what measures should be taken in this dynamic global business environment; as well as providing recommendations for future economic development and strategic decision-making. The governments should take appropriate measures in a timely manner to respond to the environmental challenges and better adapt to the new world in the post-COVID-19 era. Multinational enterprises are supposed to adjust their business models and respond with advanced international strategies. The research method of the paper is the literature review, based on which we have systematically analyzed the dynamics of international business and the current situation of globalization. Also rational strategic options are proposed for governments and multinational enterprises to consider.

Keywords: COVID-19 pandemic, international business, environmental dynamics, government, multinational enterprises, de-globalization, digitalization, national policy response.

\section{INTRODUCTION}

The COVID-19 pandemic has dramatically negative impacts on both social life and the global economy, several countries have even entered the stage of stagnation and recession [Shrestha et al., 2020]. The reports from authoritative institutions indicate that the current global economic situation is not optimistic, significant decline has occurred

This research has been conducted with financial support from St. Petersburg State University (project No. 48952283).

(C) St. Petersburg State University, 2021 
in many areas [World Trade Organization, 2020]. Meanwhile, the digitalization of communication and production seems to be an unquestionable result of this pandemic which will always accompany us, in parallel the industrial structure has also been significantly affected [Petricevic, Teece, 2019]. Investors in the tourism and hotel industries are experiencing a huge loss, and another fundamental change will be the governments' new attitudes towards the healthcare and medical industries [Alon, 2020; Panibratov, 2020]. The most shocking fact for governments and multinational enterprises (MNEs) is that they realized the existing global production chains and distribution networks are extremely vulnerable to destruction [Enderwick, Buckley, 2020]. Many of them are gradually retreating from the global integration, which leads to the economic environment with less openness and emerging phenomenon of de-globalization.

As the most worrisome change, the rapid emergence of trade protectionism and the trend of de-globalization have attracted great academic attention [Balsa-Barreiro et al., 2020]. Although the latest statistics illustrate that some countries' economies are recovering, the outbreak of the COVID-19 yet serves as an excuse for several countries and media to advocate de-globalization [Enderwick, Buckley, 2020]. However, the extant evidence of joint anti-pandemic activities across countries during the crisis, especially the Russia-China strategic cooperation, can demonstrate that globalization is not ending yet. Moreover, strengthening international cooperation can be effective in responding to the pandemic crisis and recovering from economic recession.

The present paper aims at gathering the existing literature and empirical evidence to signal the tendency of de-globalization, further providing suggestions for governments and MNEs to respond to the crisis. The COVID-19 continues to depress economic activities, many countries and MNEs are still suffering from it. To respond, policy-makers and business leaders are supposed to introduce certain advanced national policies and business strategies [Kickbusch, Leung, 2020]. MNEs could maintain their daily operation by applying digital technology, such as virtual communication, automated production, and paperless currency exchange. Besides, they should also reconsider the existing cross-border multi-step supply chains, instead introducing a more resilient system. Whether this epidemic will lead to de-globalization, governments' decisions are of vital importance. Some innovative national policies could be introduced, such as further strengthening regional cooperation, especially in the field of medicine; avoiding complete closure of the country while limiting the spread of the virus; advocating technological innovation and speeding up industrial upgrading; attracting and guiding properly foreign capital to adapt to the local environment; providing precise supports to companies and introducing preferential policies. These measures could certainly contribute to the economic recovery and maintain the process of globalization in the context of crisis.

The remainder of the paper is organized as follows. The first section is the introduction. In the second section we statistically describe the impacts of COVID-19 on the world economy. Following in the third section we present the description of dynamics that occurred during the pandemic, based on which we in the fourth section provide the conception and signs of de-globalization. Subsequently in the fifth and sixth sections we 
propose the MNEs' strategies and governments' policies in response respectively. Finally in the seventh section we conclude, articulating contribution and suggesting future research directions.

\section{THE IMPACTS OF COVID-19 ON THE WORLD ECONOMY}

Since March 2020, the worldwide COVID-19 situation has shown a great epidemic. The overall status of production and consumption in the affected countries dramatically shrank, the stock market frequently fluctuated, international trade activities greatly declined, and the risk of the global economic recession significantly accumulated [Branicki, Sullivan-Taylor, Brammer, 2021]. According to the "Global Investment Trend Monitor" from United Nations Conference on Trade and Development (UNCTAD) on January 24, 2021, global foreign direct investment (FDI) plummeted in 2020, downing $42 \%$ from last year. This is more than $30 \%$ comparing with the decline after the global financial crisis in 2009, returning to the level of the 1990s [UNCTAD, 2021]. In the light of global merchandise trade, the World Trade Organization (WTO) had lowered its forecasts and issued a press release entitled "Trade set to plunge as COVID-19 pandemic upends global economy" on April 8, 2020. According to it, the global trade level is expected to drop by $13-32 \%$ in 2020 due to the impacts of COVID-19 pandemic, which also exceed the level when the international financial crisis broke out in 2008 [World Trade Organization, 2020]. Whilst the actual global trade contraction was relatively less severe: at around 8\% according to the latest statistics. Although the COVID-19 pandemic has filled the world economy with pessimism, the reality has confirmed that the joint efforts of global economies have been effective in reducing the negative impacts of the epidemic. The Figure 1 below portrays the global merchandise trade volume.

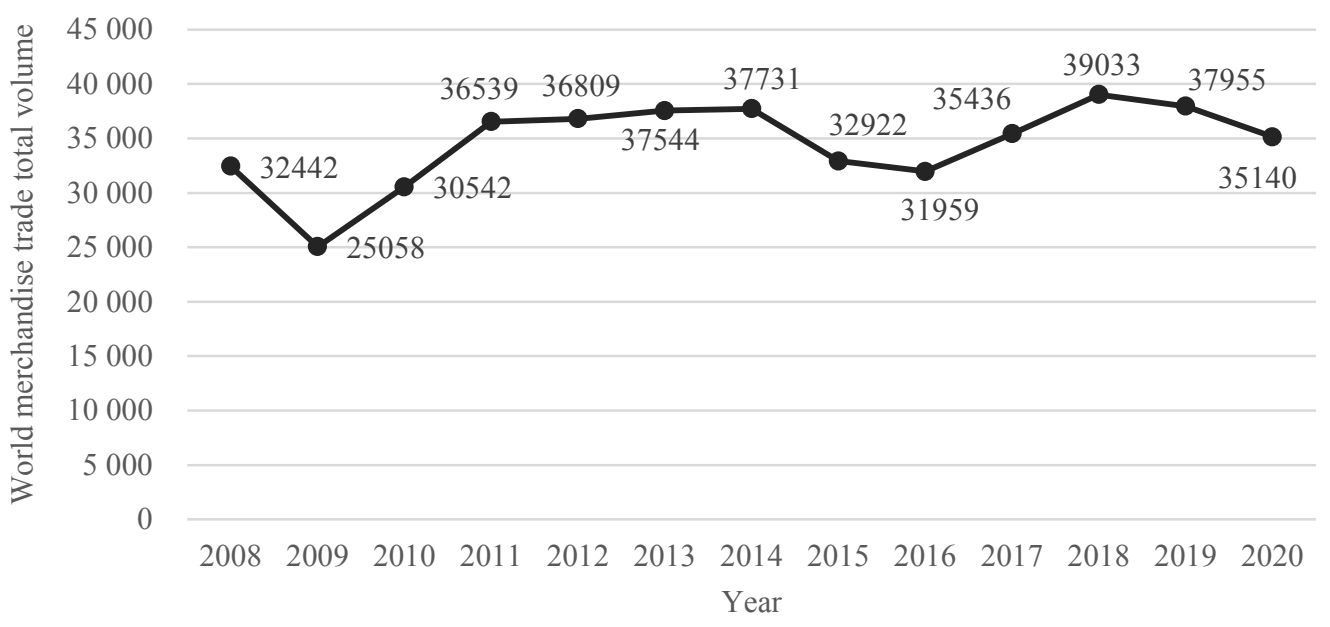

Figure 1. World merchandise trade volume, 2008-2020, billion US dollars

S o u r c e: WTO Data, 22.10.2021. 
Regarding the emerging markets, the virus pandemic caused them to fall into a huge crisis. As investors flocked to safer locations, emerging markets lost more than 100 billion dollars in foreign exchange reserves in March alone [Setser, 2020]. The international trade volume of emerging economies demonstrated a significant decline at the beginning of 2020 along with the out-of-control epidemic. Considering the cross-border movement of medical materials required to control the outbreak, there was a brief rebound within the group in March 2020. However, this is followed immediately by another decline. Thanks to the strong resilience of emerging economies, the cross-border trade slowly recovered and only returned to its pre-epidemic level by the end of 2020. Nevertheless, the growth of international trade remains precarious as the COVID-19 pandemic is not fully under control. At the beginning of 2021 emerging markets again experienced a significant contraction in international trade but are still in a phase of steady rebound recently. To describe this turbulent process, Figure 2 below portrays the monthly international trade volume of BRICS countries as the representatives of emerging markets.

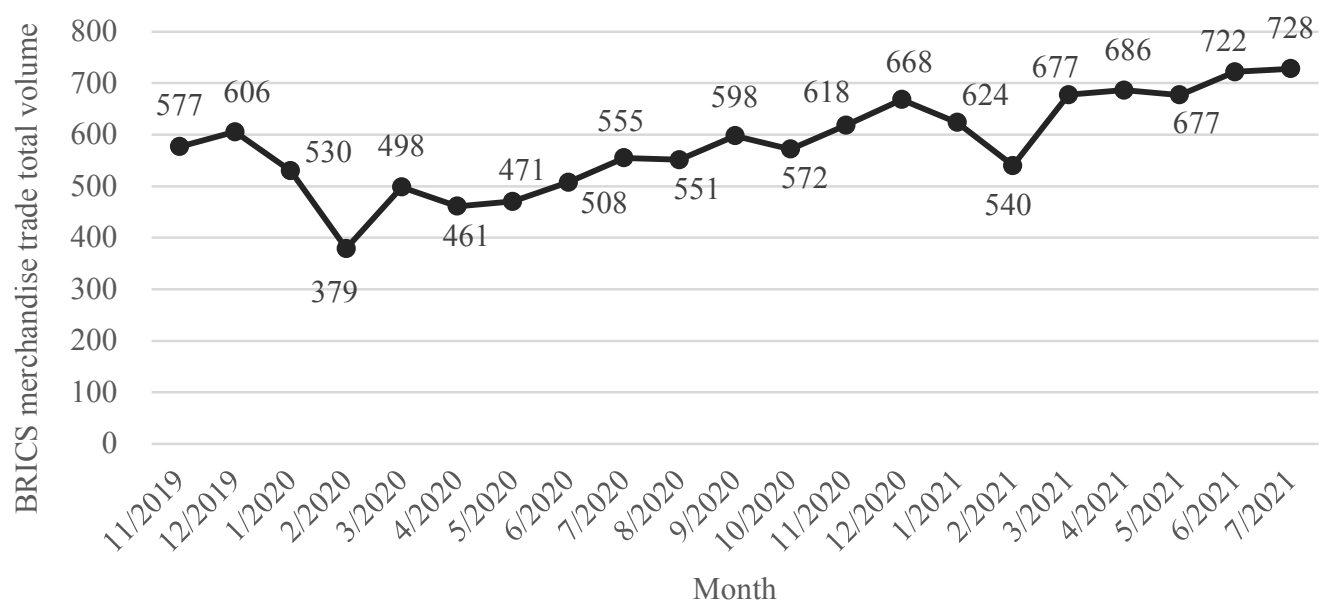

Figure 2. BRICS monthly international merchandise trade volume, billion US dollars S o u r c e: WTO Data, 22.10.2021.

During the pandemic, governments took strict measures to control the virus situation, at the same time, these measures also inevitably brought problems for production and transportation [Sułkowski, 2020]. First, the logistics and transportation services stalled due to a series of blockade measures. The products could not be delivered to their destination timely. The procurement and production of raw materials and intermediates also stagnated, which made the further production and transaction unable to proceed normally [Shrestha et al., 2020]. The countries as the places of manufacturing could not deliver the intermediate and finished products to the destination country, and the countries as the buyers also delayed the transaction dates or even canceled the orders due to the epidemic situation. Second, the production cycle of goods has been repeatedly 
extended. Due to the government's policies of extending holidays and suspending work, companies were unable to organize production, thus extending the production cycle [Hasan et al., 2021]. Because of this, many companies were unable to provide goods in time, buyers also returned goods or canceled orders frequently. It has caused frequent corporate bankruptcies. COVID-19 will continue to depress the global economic activities and reduce MNEs' productive capacity [Setser, 2020]. This seems to be an obvious observation since the number of infected people in most countries is still increasing [Ramelli, Wagner, 2020].

\section{THE WORLD AFTER CORONAVIRUS}

It is well known that countries like Russia and China are contributing significantly to the treatment and vaccine efforts for COVID-19. In these countries, large-scale vaccination is being carried out for citizens. The prospects of virus defense and treatment are promising [Du et al., 2020]. However, this far-reaching crisis can forever change our perceptions and behaviors in certain aspects. It has significantly affected social and economic life by deeply transforming the conditions of citizens and organizations [Sułkowski, 2020].

Digitalization of communication. As the most notable change stimulated by the pandemic, communication digitalization is becoming the mainstream way in modern society [Sułkowski, 2020]. In the context of the great crisis, companies, and individuals all over the world are accelerating the fourth industrial revolution [Barbieri, Darnis, 2020]. The "non-contact" methods are becoming increasingly common in daily activities, correspondingly the digital economy is spreading all over the world [Senyo, Effah, Osabutey, 2021]. Many consumption activities are performed based on digital platforms. On the individual level, one could live without directly approaching others. For enterprises, the application of digital technology could bring a relatively flexible working form without the time and place restrictions, as well as the implementation of automatic and digital factories [Almeida, Duarte Santos, Augusto Monteiro, 2020; Latukha, 2020]. Moreover, the education industry is also gradually digitalizing. For instance, an international academic conference could be held through an online form. Scholars from all over the world could attend without considering the inconvenience of time and place. The operating costs can also be significantly lowered.

There is no doubt that one of the results of the pandemic crisis is the gradual digitalization of economic and social life. Such change fundamentally occurs in different industries, such as e-education, e-office, and other digital spheres [Barbieri, Darnis, 2020]. In these industries, most activities are conducted through an appropriate digital form. During the pandemic, the stock prices of the companies Amazon and Zoom rose sharply, based on which we can see the changing direction of the future world [Almeida, Duarte Santos, Augusto Monteiro, 2020].

Tremendous changes of industrial structure. As the world is going through such a painful period, various sectors are deeply affected. The most sensitive and directly affected industries are the health, transportation, tourism, hotel industry, entertainment 
industry, and education [Sułkowski, 2020]. Investors in these industries suffered huge losses during the epidemic. Even if the epidemic situation will become better in the future, it will be much more difficult for investments in these sectors to recover, the investors will carefully consider their investment behaviors in these industries as well. Notably, the most threatened by quarantine are small and medium-sized enterprises (SMEs), who do not have enough resources to survive the crisis. Lots of collapse stories are surrounding us. Additionally, the fundamental change could also be the brand-new attitudes of governments and investors to the healthcare industry, which is based on safety management and disaster medical treatment [Amstad et al., 2020]. It should be mentioned that few specialized activities related to pharmaceutical products and medical devices even achieved great net revenue during the pandemic.

The economy with less openness. At present, COVID-19 is still forcing governments and MNEs to bear long-term self-isolation in some countries. The pandemic is creating a less open economic environment [Buckley, 2020]. Globalization enables companies to outsource production activities to foreign countries and deliver their products to foreign markets on a just-in-time basis [Gönül et al., 2021]. Originated from resources-seeking and market-seeking, companies were keeping entering foreign markets. Whereas, in the case of global disruption, firms with foreign operations are suffering significant losses. Bear this in mind, MNEs are carefully thinking about their internationalization strategies and minimizing their dependence on foreign resources and markets. In addition, the COVID-19 pandemic is partly related to the deep integration of countries around the world. The international movement of people and goods has led to the global spread of virus. This phenomenon has also alarmed governments to cautiously approach the process of globalization. The COVID-19 has triggered the idea that the mutually beneficial globalization which defined the early 21st century may disappear [Qobo, 2020].

\section{THE SIGNS OF DE-GLOBALIZATION AND THE CASE OF RUSSIA-CHINA RELATIONS}

The world economy has entered a stagnating stage, some countries have lost their confidence and motivation in globalization and international trade, which has led to the worries of global economic recession [Sułkowski, 2020]. We must acknowledge that the global business environment is locating in a terrible situation that has never appeared, the de-globalization is taking over [Alon, 2020]. The globalization process had approached a historically high level in the last few years, whilst the worldwide spread of the pandemic is driving countries to retreat from global integration. Facing the pessimistic economic situation and high interdependency among global economies, policymakers are taking deliberate measures to slow down the globalization process. Or put it another word, the de-globalization.

To control the spread of the virus and respond to the economic crisis, governments are considering gradually reducing their economic dependence on other countries, nationalizing the production and consumption activities [Witt, 2019]. Certain countries noticed their excessive economic dependence on supplies from China; their normal 
functioning of economy was significantly interrupted as soon as China began quarantines and lockdowns. Therefore, governments made decisions to ease their economic interdependency and reduce their participation level in global value chains for the sake of greater economic security. On the firm level, the big shock for multinational executives is the realization that existing global supply chain systems and distribution networks are stretched too far and easily disrupted [Alon, 2020]. MNEs are supposed to rationally shorten their current supply chains and even nationalize their operational activities [Witt, 2019]. Furthermore, in the context of weak economic growth, the tendency of trade protectionism is constantly expanding [Levy, 2021]. The outbreak of the COVID-19 has become an excuse for trade protection in some regions. Certainly, this has aggravated the rise of closed-mindedness, racial discrimination, populism, and nationalism, which fundamentally affect economic globalization, leading to the growing trade frictions and disruption of economic integration [Albertoni, Wise, 2021].

Closing borders, restricting the movement of people, canceling commercial cooperation, all will strengthen the de-globalization tendency [Qobo, 2020]. The direct result is the reduction of world trade during the crisis. As we mentioned before, the international merchandise trade in 2020 was 35.14 trillion US dollars, an 7.4\% decline comparing to the last year. In a global turbulent environment, cross-border trade struggles to stay afloat and the growth trend of the last few years ended abruptly. We can exemplify the dynamics of Sino-Russian bilateral trade in 2020 to illustrate the significant impacts of the crisis on cross-border business. According to a report released by the General Administration of Customs of China on January 14, 2021, the trade volume between Russia and China in 2020 was 107.7 billion US dollars, down by 3\% year-on-year. China exported 50.585 billion US dollars to Russia, an increase of 1\%, and imported 57.181 billion US dollars from Russia, a decrease of $6.6 \%$. The below Figure 3 presents the details about the Sino-Russian trade.

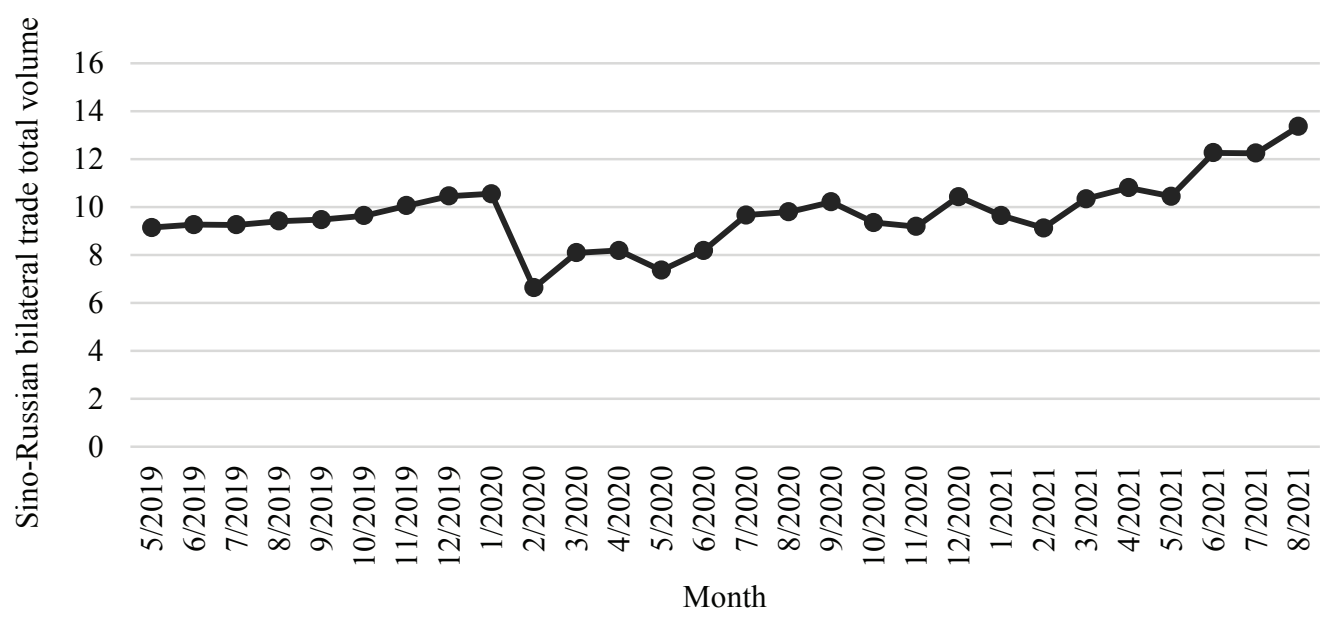

Figure 3. Monthly statistics of Sino-Russian bilateral trade, billion US dollars

S o u r c e : GACC Statistics, 22.10.2021. 
Based on the statistics, at the beginning of 2020, the total trade volume between Russia and China dropped sharply due to the pandemic of coronavirus. Closed borders and strict controls on the movement of people and goods are the main reasons for the significant decline in bilateral trade. Nevertheless, the trade volume rebounded and showed a tendency of continual growth in the second half of 2020. It is argued that the fundamental factors of Sino-Russia economic cooperation remain generally stable, showing strong resilience and great potential [Frolovskiy, 2020]. Latest figures show that Russian-Chinese trade has recovered and even surpassed the pre-pandemic level.

Bear this in mind, there is an academic debate regarding the de-globalization phenomenon [Balsa-Barreiro et al., 2020]. While some scholars are pessimistic about the future of globalization, other researchers even argue that the COVID-19 could strengthen the process of globalization. Such arguments can be supported by joint measures across countries to combat the epidemic [Guimón, Narula, 2020]. Countries shared anti-epidemic equipment, coronavirus tests, medicines, and medical equipment; they did not freeze the cross-border cooperation and turned it into a tool to deal with emergencies under the background of the pandemic and economic recession. The growing demand for coordinating anti-pandemic activities can further deepen globalization, forcing governments and international organizations to strengthen cooperation on a global scale [Sułkowski, 2020].

The case of Russia-China can further confirm such deep cooperation across countries. In recent years, Moscow and Beijing have been keeping strengthening their economic ties. Although the coronavirus crisis had delayed the communication between the two sides at the beginning of the outbreak, subsequently were more frequent dialogues between the two sides to deal with the epidemic and the recession. After the outbreak of the virus, all the core factors affecting economic growth, such as the resources, capital, and labor, have not been fundamentally affected. Both parties strive to maintain the necessary conditions for economic cooperation and keep the availability of resources, the quantity and quality of labor, and the flow of information in a stable condition. According to the "China-Russia Economic and Trade Index Report" released in September 2020, although the COVID-19 virus pandemic has put some immediate targets on hold, Russia-China bilateral trade has still maintained growth, which should be considered as good performance under such circumstances. When the global epidemic will be under full control, the bilateral exchange could even increase faster, the Sino-Russian trade volumes will soon recover and approach the levels before the pandemic [Frolovskiy, 2020].

In an environment of uncertainty, retreat from globalization is inevitable. However, this is not marking the end of globalization. Certain countermeasures must be developed and adopted. In any crisis of human history, national leaders have two equally important responsibilities: to solve the current problem and prevent them from happening again. Regarding COVID-19, the problem is how to deal with it effectively and take measures to prevent such incidents for a long time [Kickbusch, Leung, 2020]. Given the economic harms caused by pandemics, the world needs a once-in-a-century response 
[Gates, 2020]. Below we suggest specific strategies that governments and business leaders can consider and implement, to respond to the pandemic crisis and recover from economic recession.

\section{MNES' STRATEGIES IN RESPONSE}

Digitalization of communication and production. To cope with the rapid spread of the virus, enterprises are trying to digitize their business operations. Consequently, the fourth industrial revolution has been accelerated [Almeida, Duarte Santos, Augusto Monteiro, 2020]. Advanced technology is changing the dominant communication, production, and transaction modes. MNEs could take full use of such revolutionary digital changes, simultaneously pay attention to health security, curtail the travel of staff, and reduce traveling costs by working online and minimizing the possibility of person-toperson contacts [Kaszowska-Mojsa, 2020; Latukha, 2020]. What should be noted is that this is a profound revolution involving great technical innovation, companies still need to make efforts in training, motivating, and controlling employees who can adapt to the new socio-cultural patterns [Sułkowski, 2020].

Without the crisis, digitalization is still an inevitable stage in the history of human evolution [Narula et al., 2019]. The mobility restriction gives the companies opportunities to reduce travel costs, which exceeds $30 \%$ of the budgets of MNEs according to JP Morgan's investigations. The digital solutions can be effectively implemented. After the pandemic will expire, the transformation process of daily activities may be slowed down, but changes in individuals' perceptions and habits, the infrastructure constructed nowadays will continue to support digitalization [Sułkowski, 2020]. Moreover, the postCOVID-19 world will keep emerging novel forms of organizational behaviors on various technologically innovative bases [Narula et al., 2019].

Paperless monetary transformation. Recent years have witnessed the rise of paperless trading practices [Senyo, Effah, Osabutey, 2021]. COVID-19 has also accelerated the use of virtual currency. Companies such as Amazon and Alibaba are benefiting a lot from it [Hänninen, 2021]. The convenience of virtual payment improves the shopping experience of consumers, thus increasing the sales turnover. Moreover, the MNEs can avoid international bank settlement mechanisms by matching buyers and sellers online, thereby significantly reducing the international transaction costs [Alon, 2020]. Introducing electronic payment technology and the popularity of third-party electronic payment platforms is a reliable way to help companies get out of difficulties and maintain normal transactions.

The restructuring of the international supply chain. Given the vulnerability of global supply chain systems during a pandemic, MNEs need an urgent response in the short term to increase supplier diversity. The multi-step, global-scale supply chains that dominate international business today should be reconsidered in the long term [Guinea, Forsthuber, 2020]. The global supply chains were already in a bad situation before the crisis due to the rising labor costs and the continually increasing price of resources. This 
became worse because of the advances in artificial intelligence and automated production [Grenčíková, Kordoš, Berkovič, 2020]. Many strategic links within the global supply chain have now been disrupted by the restrictions on the activities of international personnel and products, worsening the governance of the supply chain system [Allen et al., 2020]. MNEs are expected to come up with new supply chain management decisions considering the scale of losses that the world has been witnessing. Instead of this globally distributed pattern, companies are supposed to come up with new supply chain management models [Barbieri et al., 2020], as well as to change their business model in an even more dramatic way [Panibratov, 2020]. In the post-COVID-19 era, they are no longer limited to considering resource allocation efficiency, the importance of resilience and sustainability of supply chain systems will also be highlighted. The improved supply chain can be diversified, regionalized, or relocated in closer proximity to countries or geographies, and be equipped with a variety of functions to avoid potential future disruptions [Alon, 2020]. In the process of restructuring the value chain of multinational corporations, such measures may cut into companies' near-term profits but indeed render the entire global system more resilient [Guinea, Forsthuber, 2020].

\section{GOVERNMENTS' POLICIES IN RESPONSE}

Strengthen cooperation and do not compromise with protectionism. We should know that no country can survive this global disaster alone [Guimón, Narula, 2020]. To restore the national economy, governments are supposed to strengthen cooperation between countries. They should firmly adhere to multilateralism in international affairs [Żak, Garncarz, 2020]. In terms of import and export, supportive policies can be used to simplify customs clearance procedures, reduce related costs, introduce more foreign exchange facilitation services, complete export tax rebates in full and in time, and make full use of export credit insurance and other tools that conform to foreign trade policies. The aim is to create a higher level of openness by lowering the tariff levels, shortening the negative lists, making more convenient market access and transparent market rules, thus creating a more attractive business environment.

As great practice, representatives of 15 countries (10 ASEAN countries, Australia, China, Japan, New Zealand, and South Korea) signed the Regional Comprehensive Economic Partnership Agreement on November 15, 2020, which is of great symbolic significance. Noteworthy, this free trade agreement was initiated and negotiated long before the pandemic (since 2012). However, participating countries were unable to agree on all elements of the agreement, the Indian government had withdrawn from the negotiations midway. Amidst serious economic risks, governments have noted the importance of strengthening international economic cooperation to cope with the recession, the signing of the agreement is appropriate to contribute to addressing the COVID-19 crisis. The pact implements zero tariffs on more than $90 \%$ of products, and intra-regional trade in 15 countries will be regarded as domestic markets. The supply and demand chains are distributed among 15 participating countries, with no tariff cost between 
links. Additionally, there are still innovative provisions in service, intellectual property protection, trade rules, and other related fields, which could certainly contribute to the economic recovery of participating countries [Petricevic, Teece, 2019]. As a "victory of multilateralism and free trade", this pact represents the willingness of governments to strengthen cooperation and jointly fight against global disaster [Żak, Garncarz, 2020]. Every country should make clear its position in the global economy and give full play to its competitiveness. The leaders of each country should make use of all possible policies to form a comprehensive and diversified multinational cooperation pattern [Guimón, Narula, 2020].

Avoiding complete closure of the country while limiting the spread of the virus. To maintain multinational business and globalization, it is necessary to control the current epidemic situation and prevent further infection, while maintaining proper mobility of personnel and products [Kickbusch, Leung, 2020]. Governments should consider taking effective measures to cope with the worldwide spread COVID-19 epidemic by strengthening cooperation in the field of health care, such as establishing a dialogue mechanism, keeping relevant information transparent and communicating, sharing community prevention experience, developing telemedicine cooperation, establishing an "Internet information platform", sharing epidemic prevention data, exchanging clinical diagnosis schemes, and jointly developing epidemics and specific drugs [Wei et al., 2021]. The purpose of these measures is not only to look after the domestic situation but also to help other countries. In addition to helping its citizens cope with it, governments can also help low- and middle-income countries strengthen their primary health care systems [Frieden et al., 2014]. By helping countries with serious epidemics, e.g., African and South Asian countries, the governments can slow down the global spread of the virus and maintain the proper exchange of personnel and goods [Shrestha et al., 2020].

For those who have to travel across borders, powerful and strict health laws and regulations are required, regardless of the epidemic situation in the destination countries [Wei et al., 2021]. Governments should strengthen risk assessment procedures, especially including the risk of infectious diseases. The Chinese government has indirectly forced citizens to download a smartphone application, which could provide the risk assessment of the personnel mobility according to visited locations. This measure enables China to continue to produce goods and services in areas that are not seriously affected by the virus [Barbieri, Darnis, 2020]. Such measures could be promoted globally and the risk of infection of those who have to cross the border can be assessed.

Strengthen technological innovation and accelerate industrial upgrading. Considering it as the most powerful measure to promote economic development, every country should pay enough attention to technological innovation and industrial upgrading. On the one hand, governments should make efforts to strengthen intellectual property protection, encourage original innovation and technological breakthroughs, and fundamentally improve the national independent innovation capabilities [KaszowskaMojsa, 2020]. On the other hand, governments should also promote the integration of 
advanced technologies, e.g., big data technology, cloud computing, artificial intelligence, and the Internet of Things with the economy and social life, improve manufacturing efficiency and social life quality through the implementation of technological innovation [Petricevic, Teece, 2019].

Particularly, the COVID-19 pandemic has exposed the serious shortage of countries' reserves of anti-epidemic materials, as well as the limited production capacity of related medical equipment. However, the production capacity of medical equipment is of great importance, and it is a hard demand for all countries [Gates, 2020]. In the post-COVID-19 era, governments of all countries should bear this lesson in mind, seize this opportunity and develop high-tech medical industries. A notable example being the "Year of Scientific and Technological Innovation" of Russia and China. This is not the direct responsive strategy to the crisis, but the pandemic has notified both sides of the importance of enhancing bilateral dialogue and strengthening scientific and technological innovation. This is the biggest cooperation project between the two countries, more than 1000 cooperative programs are included [Wang, Li, 2021]. The two sides signed the Roadmap for Sino-Russian Cooperation in Science and Technology Innovation from 2020 to 2025, established technical institutions such as the "Sino-Russian Mathematics Center". During the epidemic period, Sino-Russian cooperation in new areas such as epidemic prevention and control, vaccines and drugs' research, artificial intelligence, cloud economy, Internet of Things, and big data technology continues to strengthen.

Attract and guide foreign investment to adapt to the local environment. To facilitate the localization of FDI, governments should attract qualified companies to actively invest in their home countries, make strategic arrangements, fully absorb and utilize advanced overseas technology and management experience, and further accelerate cooperation with overseas companies. For instance, the construction of industrial parks will improve the level of overseas investment and contribute to local companies to further penetrate the global economic network [Kundurpi et al., 2021]. The innovations of government policy could make these countries ideal destinations for FDI. On June 1, 2020, the Chinese authorities issued the "Overall Plan for the Construction of Hainan Free Trade Port", which transformed the entire island province into China's largest special economic zone [Moenardy, Santoso, Dermawan, 2021]. This policy has immediately become the focus of global investors, and the innovation of preferential tax policies will surely attract a large number of FDI. In this case, the withdrawal of international capital from emerging economies has been mitigated. It will become a powerful engine for China to promote economic recovery and further develop its domestic economy.

Precise supports to companies by providing state aid. The governments should accurately analyze the current situation of domestic enterprises, step up macro-control and issue a series of supporting policies. For SMEs, the introduction of appropriate political assistance can help them reduce the impacts of the pandemic, ensure the normal operation of production and transaction. Regarding the MNEs, priority should be given to leading enterprises in the global supply chain, and key export companies should be 
supported to resume production, to ensure the stable operation of the national trade. A range of macroeconomic measures can be employed, particularly, providing state aid for enterprises severely affected by the epidemic, postponing loan and tax repayments, taking over part of the employment or social security costs by the central budget, etc. For instance, governments could take measures to promote tax refunds (tax exemption) to reduce the financial burden of companies. Besides, they could also streamline the operational processes related to economic activities under the law and reduce the number of processing steps for the business. In such a global economic downturn, the governments' assistance is the booster for the survival of enterprises [Zinecker et al., 2021].

An effective government measure during the crisis is the establishment of the PanEuropean Guarantee Fund; the first state assistance mechanism at the EU level. Not like RECP, this is the direct counteraction to cope with the pandemic shock and similar shocks in the future. Noteworthy, before the crisis, EU countries did not agree to pool funds for credit assistance to individual member states in Southern Europe, but the pandemic prompted them to do so. This unprecedented initiative pools risk among European states and offers support to the harmed business by guaranteeing commercial loans. Except for certain prohibited activities, funding is available to businesses of all sizes and in all industries. Such governments' aid is suitable for the business in the respect of alleviating a serious economic disruption.

Currently, these MNEs' responsive strategies and governments' policies have been effectively deployed to overcome the negative impacts of the pandemic. Meanwhile, business leaders and policymakers are seeking innovative ways to further improve their effectiveness. These measures not only benefit countries and firms in the context of global pandemic crisis and economic recession, moreover, taking a long-term view, they can further promote the post-pandemic world toward further globalization. The de-globalization is emerging, fortunately, the rational strategies that governments and MNEs are adopting to control the pandemic can potentially strengthen the process of globalization.

\section{CONCLUSION}

At present, the COVID-19 epidemic is continuing, its actual impacts on the economy and society depend on the duration and development degree. Given the great uncertainties in the economic environment of various countries, it is predicted that there will be further weakness in 2021. Research and reflection on the influence on social life, economic, and organizational aspects of the COVID-19 pandemic are very much needed [Sułkowski, 2020]. What is certain is that facing the rising trend of de-globalization, all governments and MNEs will not give up. Instead, they are constantly exploring the innovation of policy and business strategies to recover from the economic recession and further maintain development [Enderwick, Buckley, 2020]. It is known by all that under the new situation full of risks and challenges, countries need to actively carry out epidemic prevention work, strive to turn the crisis into development opportunities, further 
strengthen multinational cooperation and jointly promote the recovery of globalization and stable development of the world economy [Buckley, 2020].

This paper statistically portrays the significant impacts of the COVID-19 pandemic on the world economy, presents the possibilities of the future world in the post-COVID-19 era, signals the tendency of the de-globalization, and provides the author's opinion approving globalization based on literature and in-depth surveys. The influence of the pandemic on globalization still needs more empirical research. Future studies can focus on this gap and collect comprehensive empirical evidence to investigate. We have also provided potential responsive methods for governments and MNEs, emphasizing the notion of digitalization and the importance of governments' macro-manipulation measures. The effectiveness of such methods requires further exploration. The information presented in this article can serve as a springboard for further investigation into the strategies implemented during the crisis.

\section{References}

Albertoni N., Wise C. 2021. International trade norms in the age of COVID-19 nationalism on the rise? Fudan Journal of the Humanities and Social Sciences 14 (1): 41-66. https://doi.org/10.1007/ s40647-020-00288-1

Allen J. R., Burns N., Garrett L., Haass R. N., Ikenberry G. J., Mahbubani K., Menon S., Niblett R., Nye Jr. J. S., O’Neil S. K., Schake K., Walt S. M. 2020. How the world will look after the coronavirus pandemic. Foreign Policy. 20.03.2020. URL: https://foreignpolicy.com/2020/03/20/world-orderafter-coroanvirus-pandemic (accessed: 17.02.2021).

Almeida F., Duarte Santos J., Augusto Monteiro J. 2020. The challenges and opportunities in the digitalization of companies in a post-COVID-19 world. IEEE Engineering Management Review, 48 (3): 97-103. https://doi.org/10.1109/EMR.2020.3013206

Alon I. 2020. COVID-19 and international business: A viewpoint. FIIB Business Review 9 (2): 75-77. https://doi.org/10.1177/2319714520923579

Amstad M., Cornelli G., Gambacorta L., Xia D. 2020. Investors' risk attitudes in the pandemic and the stock market: New evidence based on internet searches. URL: https://www.bis.org/publ/bisbull25. htm (accessed: 17.02.2021).

Balsa-Barreiro J., Vié A., Morales A. J., Cebrián M. 2020. Deglobalization in a hyper-connected world. Palgrave Communications 6 (1): 1-4. https://doi.org/10.1057/s41599-020-0403-x.

Barbieri C., Darnis J.-P. 2020. Technology: An exit strategy for COVID-19? IAI (Istituto Affari Internazionali). URL: https://www.iai.it/en/pubblicazioni/technology-exit-strategy-covid-19 (accessed: 17.02.2021).

Barbieri P., Boffelli A., Elia S., Fratocchi L., Kalchschmidt M., Samson D. 2020. What can we learn about reshoring after COVID-19? Operations Management Research 13 (3): 131-136. https://doi. org/10.1007/s12063-020-00160-1

Branicki L., Sullivan-Taylor B., Brammer S. 2021. Towards crisis protection(ism)? COVID-19 and selective de-globalization. Critical Perspectives on International Business 17 (2): 230-251. https:// doi.org/10.1108/cpoib-05-2020-0046

Buckley P. J. 2020. The theory and empirics of the structural reshaping of globalization. Journal of International Business Studies 51 (9): 1580-1592. https://doi.org/10.1057/s41267-020-00355-5

Du J., Delis A., Douch M., Shepotylo O. 2020. Lessons from China: This is how COVID-19 could affect globalization. World Economic Forum. URL: https://www.weforum.org/agenda/2020/05/ coronavirus-globalisation-shakeup-is-inevitable (accessed: 17.02.2021). 
Enderwick P., Buckley P. J. 2020. Rising regionalization: Will the post-COVID-19 world see a retreat from globalization. Transnational Corporations 27 (2): 99-112. https://doi.org/10.18356/8008753a-en

Frieden T. R., Tappero J. W., Dowell S. F., Hien N. T., Guillaume F. D., Aceng J. R. 2014. Safer countries through global health security. The Lancet 383 (9919): 764-766. https://doi.org/10.1016/S01406736(14)60189-6

Frolovskiy D. 2020. Why China-Russia economic ties will emerge from the coronavirus pandemic stronger than ever. South China Morning Post. 25.08.2020. URL: https://www.sibur.ru/en/presscenter/publications/why_chinarussia_economic_ties_will_emerge_from_the_coronavirus_ pandemic_stronger_than_ever (accessed: 17.02.2021).

Gates B. 2020. Responding to COVID-19: A once-in-a-century pandemic? New England Journal of Medicine 382 (18): 1677-1679. https://doi.org/10.1056/NEJMp2003762

GACC Statistics. 2021. General Administration of Customs People's Republic of China URL: http://english.customs.gov.cn/statics/report/monthly.html (accessed: 22.10.2021).

Gönül S., Namlı T., Coşar A., Toroslu İ. H. 2021. A reinforcement learning based algorithm for personalization of digital, just-in-time, adaptive interventions. Artificial Intelligence in Medicine 115 (March): 102062. https://doi.org/10.1016/j.artmed.2021.102062

Grenčíková A., Kordoš M., Berkovič V. 2020. The impact of industry 4.0 on jobs creation within the small and medium-sized enterprises and family businesses in Slovakia. Administrative Sciences 10 (3): 71-91. https://doi.org/10.3390/admsci10030071

Guimón J., Narula R. 2020. Ending the COVID-19 pandemic requires more international collaboration. Research Technology Management 63 (5): 38-41. https://doi.org/10.1080/08956308.2020.17 90239

Guinea O., Forsthuber F. 2020. Globalization comes to the rescue: How dependency makes us more resilient. European Centre for International Political Economy. URL: https://ecipe.org/publications/ globalization-makes-us-more-resilient/ (accessed: 17.02.2021).

Hänninen M. 2021. Review of studies on digital transaction platforms in marketing journals. The International Review of Retail, Distribution and Consumer Research 30 (2): 164-192. https://doi.or $\mathrm{g} / 10.1080 / 09593969.2019 .1651380$

Hasan N. A., Heal R. D., Bashar A., Bablee A. L., Haque M. 2021. Impacts of COVID-19 on the finfish aquaculture industry of Bangladesh: A case study. Marine Policy 130 (March): 104577. https:// doi.org/10.1016/j.marpol.2021.104577

Kaszowska-Mojsa J. 2020. Innovation strategies of manufacturing companies during expansions and slowdowns. Entrepreneurial Business and Economics Review 8 (4): 47-66. https://doi. org/10.15678/EBER.2020.080403

Kickbusch I., Leung G. 2020. Response to the emerging novel coronavirus outbreak. The BMJ 368 (January): m406. https://doi.org/10.1136/bmj.m406

Kundurpi A., Westman L., Luederitz C., Burch S., Mercado A. 2021. Navigating between adaptation and transformation: How intermediaries support businesses in sustainability transitions. Journal of Cleaner Production 283: 125366. https://doi.org/10.1016/j.jclepro.2020.125366

Latukha M. 2020. COVID-19: The need for new talent management agenda. In: M. Marinov, S. Marinova (eds.). COVID-19 and International Business: Change of Era. New York: Routledge; $144-152$

Levy D. L. 2021. COVID-19 and global governance. Journal of Management Studies 58 (2): 562-566. https://doi.org/10.1111/joms.12654

Moenardy D. F., Santoso R. B., Dermawan W. 2021. Hainan province as the new free trade port. Turkish Journal of Computer and Mathematics Education 12 (8): 487-494. https://doi.org/10.17762/ turcomat.v12i8.2825

Narula R., Asmussen C. G., Chi T., Kundu S. K. 2019. Applying and advancing internalization theory: The multinational enterprise in the twenty-first century. Journal of International Business Studies 50 (8): 1231-1252. 
Panibratov A. 2020. Digital health business models during and post COVID-19. In: M. Marinov, S. Marinova (eds.). COVID-19 and International Business: Change of Era. New York: Routledge; 111-120.

Petricevic O., Teece D. J. 2019. The structural reshaping of globalization: Implications for strategic sectors, profiting from innovation, and the multinational enterprise. Journal of International Business Studies 50 (9): 1487-1512. https://doi.org/10.1057/s41267-019-00269-x

Qobo M. 2020. Deglobalization 2.0: Trade and openness during the great depression and the great recession. South African Journal of International Affairs 27 (2): 269-271. https://doi.org/10.1080/ 10220461.2020 .1753235

Ramelli S., Wagner A. F. 2020. Feverish stock price reactions to COVID-19. Review of Corporate Finance Studies 9 (3): 622-655. https://doi.org/10.1093/rcfs/cfaa012

Senyo P. K., Effah J., Osabutey E. L. C. 2021. Digital platformisation as public sector transformation strategy: A case of Ghana's paperless port. Technological Forecasting and Social Change 162: 120387. https://doi.org/10.1016/j.techfore.2020.120387

Setser B. W. 2020. The COVID-19 crisis in emerging markets demands a once-in-a-century response. Foreign Affairs 99 (3): 1-9.

Shrestha N., Shad M. Y., Ulvi O., Khan M. H., Karamehic-Muratovic A., Nguyen U. S. D. T., Baghbanzadeh M., Wardrup R., Aghamohammadi N., Cervantes D., Nahiduzzaman K. M., Zaki R. A., Haque U. 2020. The impact of COVID-19 on globalization. One Health 11: 100180. https://doi. org/10.1016/j.onehlt.2020.100180

Sułkowski Ł. 2020. COVID-19 pandemic; recession, virtual revolution leading to de-globalization? Journal of Intercultural Management 12 (1): 1-11. https://doi.org/10.2478/joim-2020-0029

UNCTAD. 2021. Global Investment Trend Monitor. No. 38. URL: https://unctad.org/webflyer/globalinvestment-trend-monitor-no-38 (accessed: 17.02.2021).

Wang P., Li F. 2021. Science, technology and innovation policy in Russia and China - Mapping and comparisons in objectives, instruments and implementation. Technological Forecasting and Social Change 162: 120386. https://doi.org/10.1016/j.techfore.2020.120386

Wei Y., Wang J., Song W., Xiu C., Ma L., Pei T. 2021. Spread of COVID-19 in China: Analysis from a city-based epidemic and mobility model. Cities 110: 103010. https://doi.org/10.1016/j.cities.2020.103010

Witt M. A. 2019. De-globalization: Theories, predictions, and opportunities for international business research. Journal of International Business Studies 50 (7): 1053-1077. https://doi.org/10.1057/ s41267-019-00219-7

World Trade Organization. 2020. Trade statistics and outlook: Trade set to plunge as COVID-19 pandemic upends global economy. WTO Trade Forecast Press Conference. URL: https://www.wto. org/english/news_e/pres20_e/pr855_e.htm (accessed: 17.02.2021).

WTO Data. 2021. World Trade Organization Data Portal. URL: https://timeseries.wto.org (accessed: 22.10.2021).

Żak M., Garncarz J. 2020. Economic policy towards the challenges of the COVID-19 pandemic in selected European Union countries. International Entrepreneurship Review 6 (4): 21-34.

Zinecker M., Doubravský K., Balcerzak A. P., Pietrzak M. B., Dohnal M. 2021. The COVID-19 disease and policy response to mitigate the economic impact in the EU. Technological and Economic Development of Economy 27 (3): 742-762. https://doi.org/10.3846/tede.2021.14585

Received: May 11, 2021

Accepted: August 6, 2021

Contact information

Andrei Yu. Panibratov - Dr. Sci. in Economics, Professor; panibratov@gsom.spbu.ru

Shenglong Chen - Postgraduate Student; Shenglong.Chen@spbu.ru 


\title{
ПРИМИРИТЬСЯ С ДЕГЛОБАЛИЗАЦИЕЙ ИЛИ ВОСПОЛЬЗОВАТЬСЯ ЭТОЙ ВОЗМОЖНОСТЬЮ? ПОСЛЕДСТВИЯ ПАНДЕМИИ COVID-19 ДЛЯ КОМПАНИЙ И ГОСУДАРСТВА
}

\author{
А. Ю. Панибратов, Ш. Чэнь \\ Санкт-Петербургский государственный университет, \\ Российская Федерация, 199034, Санкт-Петербург, Университетская наб., 7-9
}

Для цитирования: Panibratov A. Yu., Chen S. 2021. Compromising with deglobalization or seizing an opportunity? Implications of the COVID-19 pandemic for firms and governments. Вестник Санкт-Петербургского университета. Менеджмент 20 (3): 326-342. http://doi.org/10.21638/11701/spbu08.2021.302

В статье представлена попытка исследования адаптивной национальной политики и стратегии бизнеса на основе осмысления последствий пандемии COVID-19. В то время как мировая экономика предпринимает усилия по восстановлению от потерь, связанных с пандемией, многим видам предпринимательской деятельности был нанесен непоправимый ущерб. Одновременно с этим проявляются тенденции, связанные с деглобализацией, сопровождающейся цифровизацией коммуникаций и трансформацией отраслей. В связи с этим необходимо понять, какие меры следует предпринять в динамичной глобальной среде бизнеса, а также дать рекомендации относительно будущего экономического развития и принятия стратегических решений компаниями и государствами. Национальным правительствам необходимо быстро реагировать на изменения в среде бизнеса и адаптироваться к новым реалиям после пандемии COVID-19. Многонациональные компании должны иметь возможность корректировать свои бизнес-модели и формировать передовые бизнес-стратегии. В работе представлен обзор литературы, на основе которого анализируется динамика международного бизнеса и текущей ситуации глобализации, а также предлагаются стратегические варианты, которые целесообразно принять во внимание правительствам и многонациональным компаниям.

Ключевые слова: пандемия COVID-19, международный бизнес, динамика окружающей среды, правительство, многонациональные предприятия, деглобализация, цифровизация, национальная политика, ответные меры.

Статья поступила в редакцию 11 мая 2021 г.

Статья рекомендована в печать 6 августа 2021 г.

Контактная информация

Панибратов Андрей Юрьевич - д-р экон. наук, проф.; panibratov@gsom.spbu.ru

Чэнь Шэнлун - аспирант; Shenglong.Chen@spbu.ru

Исследование выполнено при финансовой поддержке Санкт-Петербургского государственного университета (проект № 48952283). 